\title{
The Effect of Top Management Involvement on Supply Chain Risk Management through Buyer-Supplier Relationship
}

\author{
Hotlan Siagian $^{1 *}$, Zeplin Jiwa Husada Tarigan${ }^{1}$, Han Tae Hee ${ }^{2}$
}

\begin{abstract}
This paper aims to examine the role of the buyer-supplier relationship in improving the impact of top management involvement in the supply chain risk management. The study used 55 export-oriented manufacturing companies domiciled in East Java of Indonesia, and three respondents from top management level represented each company. Of 55, 44 companies have completed the questionnaires which means the response rate of $80 \%$. Data collection used a questionnaire designed with a five-item Likert scale. Data analysis used the partial least square technique with Smart-PLS software version 3.0 to examine the hypotheses. The finding revealed that top management involvement affects supply chain risk management, top management involvement affects the buyer-supplier relationship, and buyer-supplier relationship affects supply chain risk management. The last finding is that buyer-supplier relationship empirically the effect of top management involvement. This paper paves the way for the manager in improving supply chain risk management by practicing top management involvement and development of a relationship with the supplier.
\end{abstract}

Keywords: Top management involvement, supply chain risk management, buyer-supplier relationship.

\section{Introduction}

International trade and globalization are increasingly affecting the logistics system. As a company is expanding for global networking, it has to set up a logistics system connected with other companies in other countries. This logistic system is crucial in the attempt of importing raw material or exporting the finished product. The integration among firms that form a flow of material, goods, service, and information between supplier, manufacturer, distributors, agents, and last customers is dealt with a supply chain management (Chan and Prakash [1]). In today's competitive environment, the competition is not on the product alone but also on the supply chain performance in term of cost efficiency and responsiveness. Hence, business success will depend on management's ability to integrate all the companies connected on the supply chain network of a business to deliver the product with a minimum cost and excellent responsiveness (Ellram and Cooper [2]; Hsu et al. [3]). A higher supply chain risk emerges as the supply chain network more complex, and more organizations are involved in the supply chain. Initial interviews with several leaders of South Korean companies in East Java, Indonesia, revealed that several risks and obstacles had emerged in the supply chain activities process such as inconsistent product quality, unstable product prices, and late product delivery.

\footnotetext{
${ }^{1}$ Faculty of Economics, Magister Management, Petra Christian University, Лl. Siwalankerto 121-131, Surabaya, Jawa Timur, Indonesia, 60238. Email: siagian@petra.ac.id, zeplin@petra.ac.id. 213, Oegapcheon-ro 107 beon-gil, Daegwandae-ri, Gapcheon-myeon, Hoengseong-gun, Gangwon-do, Republic of Korea.

* Corresponding author
}

Supply chain risk management is a concept of mitigating the risk of any supply chain in the pursuit of reducing or eliminating the consequences of any disruption on the supply chain activities. Many studies have been conducted to define and measure the supply chain risk management (Elram and Cooper [2]; Blos et al. [4]; Hollstein [5]; Narasimhan and Talluri [6]; Stock et al. [7]). A supply chain risk management should appropriately be implemented to anticipate and resolve any risk result from any disruption in the supply chain process. Furtherly, the question raised is how to improve the supply chain risk management. Several studies have revealed that buyers-supplier relationship is one of the factors that can enhance the supply chain risk management (Breuer et al. [8]; Hudnurkar and Rathod [9]). Other researchers found that top management involvement, particularly in decision making, also contribute to influencing the successful implementtation of the supply chain risk management (Ingley and Walt [10]). Meanwhile, another research by Seppanen et al. [11] stated that top management involvement influences the establishment of the buyer-supplier relationship.

In summary, the above discussion has revealed at least two constructs that can improve the supply chain risk management. However, those studies extensively focused on the direct influence of top management involvement and the buyer-supplier relationship in enhancing the supply chain risk management. So far, to the best of our knowledge, there has been no study examining the relationship of the top management involvement, buyer-supplier relationship, and the supply chain risk management simultaneously. To fill this gap, the present study, 
focus on the influence of top management involvement on the supply chain risk management through the mediating role of the buyer-supplier relationship. This study, therefore, addresses four research questions: (a) if the top management involvement affects the buyer-supplier relationship, (b) if the top management involvement influences the supply chain risk management, and (c) if the buyer-supplier affects the supply chain risk management, and (d) if the top management involvement indirectly affects the supply chain management risk through the buyersupplier relationship.

\section{Methods}

\section{Top Management Involvement}

Found that Top Management needs to devote time, energy and financial resources to support the development of relationships with suppliers ( $\mathrm{Zu}$ et al. [12]). Since Top Management is the one who is usually most aware of the company's strategic imperatives to stay competitive in the market and they have a better understanding of supply chain risk management. This study defined top management involvement as the extent to which the management intervene the process of decision making. It is assessed using four indicators namely: (a) the intervention of the top management in planning the long-run business plan, (b) the relevance of the decision on the short-term and day-today operation, (c) the promoting collaboration among people from different functional areas involved in supply chain risk management, and (d) an intervention in determining the critical organization's performance.

\section{Supply Chain Risk Management}

In today's competitive environment, the success of a single business will depend on management ability to integrate the company complex network of business relationships (Ellram and Cooper, [2]). Building a network of relationships between organizations, as well as all business units, is another component of the theme of activities identified in the definition of supply chain management. The definetion cites the relationship network as a fundamental aspect in which the relationship refers to the right relationships with external organizations such as suppliers and internals with all business units, or a combination of both (Stock et al. [7]). Supply chain offers an opportunity to capture synergies in dealing with the overall business process and is a new way of managing firms and relationships with other members of the supply chain. As described previously, each supply chain has its own risk raised from any disruption happening in the supply chain process. The management should create or develop a scenario to reduce and eliminate the risk or the consequences in case the presence of an abnormality in the supply chain integrity. Supply chain risk management refers to the approach developed by the organization to handle any disruption in the supply chain, and initially, it was used in the contexts of logistic, which emphasized the reductions in inventory within the organization. This concept, in general, is still new and is unknown to many companies (Blos et al. [4]). The objectives of the management are to identify potential sources of risk and take appropriate action to avoid or stem supply chain vulnerabilities (Narasimhan and Talluri [6]).

To strengthen the structure of supply chains processes, and networks, adequate risk management needs to be built and utilized (Hollstein [5]). The important point lies in the flexibility of the process. Better network provisioning and monitoring through technology and communications infrastructure will be increasingly needed while supply chain management improvements on the standard procedure, flexibility, and redundancy should usually be balanced (Hollstein [5]). Supply chain risk management measure the extent to which management make decision in term of (a) preparing a redundancy plan in case a significant disruption of supply chain activities, (b) preparing a proactive system and procedure to ensure the business continuity, and (c) the flexibility in investment option in managing the threat from weak partner in the supply chain.

\section{Buyer-Supplier Relationship}

Supply Chain Management deals with suppliers and buyers. The buyer-supplier relationship is one of the essential activities in supporting the company's strategy. The company, therefore, needs to maintain an appropriate relationship with its provider. An excellent buyer- suppliers is an integral part of the business that is always associated with building the business (Ambrose et al. [13]). The buyer-supplier relationship has an impact on the strategy and operational level in enhancing the quality of production, innovation, and reduce costs to pursue a competitive advantage (Hsu et al. [3]). The relationship also supports the companies in achieving the long-term goals and profit. Those studies addressed that buyer-supplier relationship is the extent to which the buyer and supplier (a) keep the promise as agreed without harming either party, (b) have empathy from each party to understand what both sides want, (c) the existence of mutual support and decision, and (d) the presence of a social relationship between buyer and supplier.

\section{The Relationship of Top Management Involve- ment and Supply Chain Risk Management}

Balancing risk and rewards is never more challenging than it is today. Companies face a more complex and interconnected risk than ever before. Therefore, top management involvement such as chief financial 
officer (CFO) or chief audit executive plays a significant role in risk (Viscelli et al. [14]). Top management should involve themselves in the risk management process by providing leadership, authority, and supervision (Ingley and Walt [10]). This includes the contribution of expertise and assessment to the strategic process, define and communicate risk tolerance limits for the employees to guide their decisions, empowering employees to manage risk within a prescribed tolerance level, and oversee the implementation of corporate risk management processes (Ingley and Walt [10]). Because top management provides risk management oversight, they need to understand the management process to assess and respond to significant risks. Top management needs to be involved in regularly discussing and challenging fundamental assumptions and procedures underlying management to draw up and implement risk management processes. Effective top management should understand how a company identifies and manages risks (Aven [15]). Also, they will need to understand how management develops an estimate of potential hazards or potential impacts. Top management should have a process to identify and assess risks that arise. Top management can also provide guidance on the role of risk oversight from various industry regulators and private organizations that publish best practice recommendations (Frigo and Anderson [16]). Based on the above description, this study proposes first hypotheses as follow:

H1: Top management involvement affect supply chain risk management

\section{The Relationship of Top Management Involve- ment and Buyer-Supplier Relationship}

According to Seppanen et al. [11], it is necessary to determine whether the existing Relationship takes place on an interpersonal or organizational level. Although this phenomenon is mostly related to personal Relationship and Personal Relationship is considered more powerful and more important, but the inter-organizational relationship is the most valid Seppanen et al. [11]. Therefore, top management should be involved to ensure that relationships built between individuals in the organization. Even if the employee stops working for the companies, the relationship between the two sides will only deteriorate slightly, but it will not disappear. Top management needs to develop an internal system that will provide the possibility that relationships that were initially developed at the individual level move to the corporate level. Companies need to make sure that whatever mutual trust relationships are developed, the relationship will continue to grow because of the character and the rules of the company, not because of specific jobs. Top management needs to compare the level of confidence and level of perceived risk, and then decide to engage in a relationship with others. Top management involvement is essential to make sure that the relationship with the supplier would provide a benefit for the company in the short term and long term. Top management would be able to achieve this expected mutual benefit since top management makes a company decision. Therefore, propose the second hypotheses as follows:

H2: Top management involvement affects the buyer-supplier relationship

The Relationship of Buyer-Supplier Relationship and Supply Chain Risk Management

Close coordination between partner increases dependence on each other as risks can arise for individual companies as well as for the entire supply chain. Therefore, Relationship to achieve collaboration between partner becomes necessary (Breuer et al. [8]). An essential element of supply chain collaboration is the integration and synchronization of the company's business processes with the business processes of its partner supplying company. Business processes cover information sharing and handling financial flows as well. The performance of supply chain risk management could be improved by managing and coordinating the flow of information and financial (Breuer et al.[8]; Hudnurkar and Rathod [9]). With the accurate flow of information between partners, the decision making by both parties will be proper and make sure the decision is correct. Based on this description, the last hypotheses is proposed as follows:

H3: Buyer-supplier relationship affects supply chain risk management.

\section{The Mediating Role of Buyer-Supplier Relation- ship Management}

As described above, top management involvement affects buyer-supplier relationship because the top management decides to establish a relationship with the supplier (Seppanen et al. [11]). Other studies suggested that the buyer-supplier relationship has an impact on the supply chain risk management because a good relationship with a supplier can avoid the risk due to interruption of the supply chain activities the (Breuer et al.[8]; Hudnurkar and Rathod [9]). As the top management involvement affects the buyer-supplier relationship, and the buyer-supplier relationship affects the supply chain risk management, we can postulate that the buyersupplier relationship mediates the relationship between top management involvement and the supply chain risk management. Hence, propose the fourth hypotheses as follow:

H4: Buyer-supplier relationship mediates the relationship between top management involvement and supply chain management. 
Table 1. Operational definition and statistic value of indicator

\begin{tabular}{lccc}
\hline Variable and Indicator & Mean & St.Dev. & Factor Loading \\
\hline Top Management involvement [12] & & & 0.670 \\
- (X11) Top management decides on the long run plan & 4.11 & 0.492 & 0.737 \\
- (X12) Top management decision is relevant & 4.11 & 0.618 & 0.769 \\
- (X13) Top management has an active role in collaborating with people & 3.93 & 0.625 & 0.857 \\
- (X14) Top management intervening key organization performance & 4.00 & 0.682 & 0.741 \\
\hline Buyer-supplier relationship [3] & & & 0.812 \\
- (X21) Buyer and supplier keep the promise as agreed & 4.07 & 0.586 & 0.729 \\
- (X22) Buyer and supplier have an empathy & 4.02 & 0.549 & 0.732 \\
- (X23) Buyer and supplier give mutual support and decision & 4,04 & 0.480 \\
- (X24) Social relationship between buyer and supplier exists & 4.04 & 0.545 & 0.780 \\
Supply chain risk management [5] & & & 0.736 \\
- (X31) Management prepared redundancy plan & 4.07 & 0.632 & 0.813 \\
- (X32) Settlement of a proactive system and Procedure system \& procedures & 4.14 & 0.492 & 0.462 \\
- (X33) Flexibility in managing the threat from weak partners. & 4.19 & 0.462 & \\
\hline
\end{tabular}

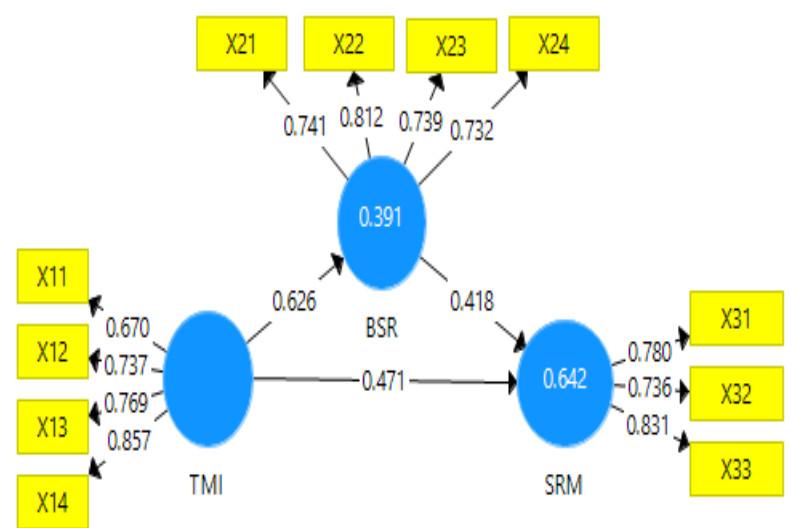

Figure 1. Research Model of the Study

\section{Sample and Data Collection}

This study focuses on the 55 export-oriented Manufacturer companies domiciled in East Java. These companies are considered facing higher supply chain risk as they manage more complicated supply chain network. They are importing raw material and also exporting the final product abroad. Three respondents represented each company from top management levels, such as CEO, General Manager and another highest ranking official as they are the person most knowledgeable of the firm particularly in respect of related variables being studied. Hence, questionnaires were distributed to 165 respondents representing 55 export-oriented manufacturing companies. An interview and discussion have been conducted with several respondents to make sure the data are correct. The questionnaire is designed using subjective multi-item indices to measure each manifested variables or indicator using a five-point Likert-type scale from $1=$ strongly disagree up to $5=$ strongly agree. Of the total 55 firms, 44 have correctly completed the questionnaires representing the response rate of $80 \%$. Data were analyzed with
Partial least square (smartPLS) software version 3.0 to assess the validity of the measurement model, and the path coefficient of each construct relationship. PLS is an appropriate tool for analyzing the data particularly in the case small sample size and limited theoretical knowledge (Moreno and Casiilas [17]). PLS offers a predictive capability in the event of limited literature reference such as in this study and appropriate for multi-scales measurement.

\section{Operational Definition of Variables}

The operational definition and the statistic value of each indicator of the variable are demonstrated in Table 1 . This Table also indicated the factor loading of each indicator.

\section{Results and Discussions}

The first analysis is to assess the measurement model (outer model) by evaluating the convergent, discriminant validity of each indicator and the reliability of the block indicators of each variable. The next step is to examine the structural model (inner model) through the assessment of the patch coefficient together with its p-value or t-value to examine if the hypotheses supported or not. To test the hypotheses, it refers to the best practice acceptable limit. Factor loading of each indicator should exceed 0.5 for convergent validity. Meanwhile, for the discriminant validity, cross loading of each indicator should be higher than its loading with another construct. Beside the validity, block indicators of each variable should have composite reliability greater than 0.7. For hypotheses testing, we look at the path coefficient of each hypothesis and its $t$-value. For the significance level of $5 \%$, the $t$-value should be higher than 1.96 for the hypotheses to be accepted. 
Table 2. Average variance extracted (AVE) and reliability of each variable

\begin{tabular}{|c|c|c|c|c|}
\hline Variable & AVE & CR & $\begin{array}{l}\text { Cron. } \\
\text { Alpha }\end{array}$ & R Square \\
\hline $\begin{array}{l}\text { Top management } \\
\text { involvement (TMI) }\end{array}$ & 0.580 & 0.845 & 0,756 & \\
\hline $\begin{array}{l}\text { Buyer-supplier } \\
\text { relationship (BSR) }\end{array}$ & 0.573 & 0.842 & 0,754 & 0.391 \\
\hline $\begin{array}{l}\text { Supply chain risk } \\
\text { management (SRM) }\end{array}$ & 0.614 & 0.826 & 0,684 & 0.642 \\
\hline
\end{tabular}

Table 3. Path coefficient and T-statistic

\begin{tabular}{lccc}
\hline Hypotheses & $\begin{array}{c}\text { Original } \\
\text { estimate (B) }\end{array}$ & t- statistic & P-value \\
\hline TMI -> SRM (H1) & 0.471 & 3.512 & 0.000 \\
TMI -> BSR (H2) & 0.626 & 9.604 & 0.000 \\
BSR -> SRM (H3) & 0.418 & 3.823 & 0.000 \\
TMI -> SRM -> SRM (H4) & 0.261 & 3.235 & 0.001 \\
\hline
\end{tabular}

As indicated in Table 1, those indicators of each variable are valid as the value of factor loading exceeds the recommended minimum value of 0.50 , in all cases (range 0.670 to 0.857 ). Hence, all indicators are considered valid in term of convergent validity. From the analysis result also found that the discriminant validity of all indicators is acceptable since the cross loading of each indicator with other variables is less than its factor loading. Table 2 lists the value of average variance extracted (AVE), composite reliability (CR) and Cronbach alpha. The composite reliability and Cronbach alpha exceeded the recommended minimum value of 0.70 , except for the SRM, which approach 0.70. Since the composite reliability exceeds 0.70 , we considered all the construct are reliable. The value of AVE exceeded the accepted minimum value of 0.50 in all cases (range 0.573 to 0.614 ).

This magnitude of AVE demonstrated that the measurement model has an acceptable discriminant validity in all cases. The bootstrapping method was used to extract $t$-value to ascertain the significance level of each path coefficient to examine if the hypotheses supported or not. The primary method used to assess the inner model is by examining the variance explained called $\mathrm{R}^{2}$. Table 2 lists the variance explained $\left(R^{2}\right)$ for each dependent variable, i.e., buyer-supplier relationship and supplier chain risk management. This value of $\mathrm{R}^{2}$ is comparable to values typically reported in performance research. Other measurement used to assess the inner model is its predictive relevance which is denoted as $\mathrm{Q}^{2}=1$ $\left(1-R_{1}{ }^{2}\right)\left(1-R_{2}{ }^{2}\right)$. This value depends on the value of $R^{2}$ of each endogenous construct. The value of $\mathrm{Q}^{2}$ ranging from 0.00 to 1.00 . As the value approach to 1.00 , the better is the power of the inner model. The result of $\mathrm{Q}^{2}$ is 0.660 which means that independent variables have a substantial impact in predicting dependent variables.
Next analysis is to examine those hypotheses by referring to the value of each path coefficient and $t$ value or $p$-value obtained from PLS result. Table 3 lists the path coefficient (B), $t$-value, and $p$-value for each relationship.

Based on the significance level of $5 \%$ or t-value of 1.96 , the results demonstrated that all path coefficients are positive and significant. As expected, top management involvement $(B=0.471$ and $\mathrm{t}$-value $=$ 3.512) influence the supply chain risk management. This result confirms the previous research saying that top management involvement affects the supply chain risk management, and supported hypotheses H1. Furthermore, top management involvement ( $B$ $=0.626$ and $t$-value $=9.604$ ) have a direct impact on the buyer-supplier relationship. This result is consistent with previous research on the relationship between top management involvement in the buyersupplier relationship, and hence, it supported hypotheses H2. The next finding is that the buyersupplier relationship affects the supply chain risk management $(B=0.418$ and $t$-value $=3.823)$. The last finding is that top management involvement indirectly affects the supply chain risk management through the mediating role of buyer-supplier relationship $(B=0.261$ and $t$-value $=3.235)$. As a result, all hypotheses $\mathrm{H} 1, \mathrm{H} 2, \mathrm{H} 3, \mathrm{H} 4$, are supported as expected. Figure 1 shows the complete result of analysis using PLS.

It has been addressed previously that the primary purpose of this study was to examine the mediating role of the buyer-supplier relationship. Interestingly, buyer-supplier relationship indeed mediates the impact of top management involvement in the supply chain risk management. This result revealed that the top management involvement has a direct and indirect effect on supply chain risk management. In another word, the existence of the buyersupplier relationship is highly critical to the success of the supply chain risk management through its direct and indirect influence.

\section{Discussion}

The present work reveals that top management involvement affects supply chain risk management through the buyer-supplier relationship. The findings prove the agreement of the result with the previous study (Ingley and Walt [10]). This finding suggests that the participation of the top management is critical to the success of supply chain risk management. To minimize the risk in the supply chain, it needs high-level management involvement in the long run business plan establishment, promoting collaboration among different functional area, 
and deciding investment and resources allocation. This top management involvement allows the organization to establish a strategy in collaboration with their partners to determine a plan in case of disruption, to prepare a procedure to ensure the business continuity and the flexibility in investment option in managing the threat from weak. The result is considered reasonable since one of the strategies in anticipating the risk is the establishment of a redundancy plan in case any disruption in the supply chain process. Of course, the redundancy plan cannot be set forth without cooperation with the supplier. One of the most exciting findings, however, was the significant mediating role of the buyersupplier relationship in enhancing the supply chain risk management. This result, consequently, implies that top management involvement has a double impact in supporting the success of supply chain risk management. The first one is due to its direct influence and the second is its indirect impact on the mediating role of the buyer-supplier relationship. Hence, the management should establish an excellent mutual relationship with its supplier. In summary, this result paves the way for the manager to intensively involve the top management and establish an excellent relationship with its supplier in implementing supply chain risk management, to reduce or eliminate any risk in case any disruption in the supply chain process.

\section{Conclusion}

The primary aim of the present research was to examine the mediating role of the buyer-supplier relationship on the influence of top management involvement in the supply chain risk management. The results prove that indeed buyer-supplier relationship mediates the relationship between top management involvement and the supply chain risk management. The finding has revealed that all proposed hypothesis, as expected, are supported. This study has also shown the two constructs, top management involvement and buyer-supplier relationship, have a direct impact on the supply chain risk management. In addition to the direct influence, top management involvement also indirectly affect the success of the supply chain risk management. Based on this result, the success of supply chain risk management can reasonably be enhanced by building top management involvement and the establishment of the buyer-supplier relationship. This study provides insight for and supports the industrial manager to improve the supply chain risk management through practicing top management involvement and establishing an excellent relationship with the supplier.

\section{References}

1. Chan, F. T. S., and Prakash, A., Inventory Management in a Lateral Collaborative Manufacturing Supply Chain: a Simulation Study, International Journal of Production Research, 50(16), 2012, pp. 4670-4685.

2. Ellram, L. M., and Cooper, M. C., Supply Chain Management: It is All About the Journey, Not the Destination, Journal of Supply Chain Management, 50(1), 2014, pp. 8-20.

3. Hsu, C., Kannan, V. R., Tan, K., and Leong, G. K., Information Sharing, Buyer Supplier Relationships, and Firm Performance, International Journal of Physical Distribution \& Logistics Management, 38(4), 2008, pp. 296-310.

4. Blos, M. F., Quaddus, M., Wee, H., and Watanabe, K., Supply Chain Risk Management (SCRM): a Case Study on the Automotive and Electronic Industries in Brazil. [em], Supply Chain Management: An International Journal, 14(4), 2009, pp. 247-252.

5. Hollstein C., H. F., Supply Chain Risk Management, Log Forum, 9(1), 2013, pp. 21-25.

6. Narasimhan, R., and Talluri, S., Perspectives on Risk Management in Supply Chains, Journal of Operations Management, 27(2), 2009, pp. 114118.

7. Stock, J. R., Boyer, S. L., and Harmon, T., Research Opportunities in Supply Chain Management, Journal of the Academy of Marketing Science, 38(1), 2010, pp. 32-41.

8. Breuer, C., Siestrup, G., Haasis, H.-D., and Wildebrand, H., Collaborative Risk Management in Sensitive Logistics Nodes, Team Performance Management, 9(7/8), 2013, pp. 331-351.

9. Hudnurkar, M., and Rathod, U., Collaborative Supply Chain: Insights from the Simulation, International Journal of Systems Assurance Engineering and Management, 3(2), 2012, pp. 122-144.

10. Ingley, C., and Walt, N.V.D., Risk Management, and Board Effectiveness, International Studies of Management and Organization, 38(3), 2008, pp. 43-70.

11. Seppanen, R., Blomqvist, K., and Sundqvist, S., Measuring Inter-organizational Trust - a Critical Review of the Empirical Research in 19902003, Industrial Marketing Management, 36(2), 2007, pp. 249-265.

12. Zu, X., Fredendall, L. D., and Douglas, T. J., The Evolving Theory of Quality Management: The Role of Six Sigma, Journal of Operations Management, 26(5), 2008, pp. 630-650.

13. Ambrose, E., Marshall, D., Fynes, B., and Lynch, D., Communication Media Selection in BuyerSupplier Relationships", International Journal of Operations \& Production Management, 28 (4), 2008, pp. 360-379. 
14. Viscelli, T.R., Beasley, M.S., and Hermanson, D.R., Research Insights into Risk Governance: Implications from a Review of ERM research, SAGE open, 2016, pp. 1-17.

15. Aven, T., Risk Assessment and Risk Management: A Review of Recent Advances on Their Foundation, European Journal of Operational Research, 253 (1), 2016, pp. 1-13.
16. Frigo, M. L., and Anderson, R. J., Strategic Risk Management: A Foundation for Improving Enterprise Risk Management and Governance, The Journal of Corporate Accounting \& Finance, 22(3), 2011, pp. 81-88

17. Moreno, A., and Casiilas J., Entrepreneurial Orientation and Growth of SMEs: A Causal Model, Entrepreneurship Theory and Practice, 32(2), 2008, pp. 507-528. 